Article

\title{
Optimizing Yield and Quality of Silage and Hay for Pea-Barley Mixtures Ratio under Irrigated Arid Environments
}

\author{
Walid Soufan *(D) and Nasser A. Al-Suhaibani
}

check for updates

Citation: Soufan, W.; Al-Suhaibani, N.A. Optimizing Yield and Quality of Silage and Hay for Pea-Barley Mixtures Ratio under Irrigated Arid Environments. Sustainability 2021, 13, 13621. https://doi.org/10.3390/ su132413621

Academic Editors: M. Iftikhar Hussain, Awais Shakoor, Sher Muhammad Shahzad, Taimoor Hassan Farooq and Steve W. Lyon

Received: 19 October 2021

Accepted: 6 December 2021

Published: 9 December 2021

Publisher's Note: MDPI stays neutral with regard to jurisdictional claims in published maps and institutional affiliations.

Copyright: (c) 2021 by the authors. Licensee MDPI, Basel, Switzerland. This article is an open access article distributed under the terms and conditions of the Creative Commons Attribution (CC BY) license (https:// creativecommons.org/licenses/by/ $4.0 /)$.
Plant Production Department, College of Food and Agriculture Sciences, King Saud University, P.O. Box 2460, Riyadh 11451, Saudi Arabia; nsuhaib@ksu.edu.sa

* Correspondence: wsoufan@ksu.edu.sa

\begin{abstract}
The changing climate, water scarcity, reduction in the land area under forage crops, expanding ruminant population, burgeoning demands for milk and meat production and food security concerns all insist on a necessary increase in forage production and quality. Cereal-legume mixed intercropping offers a biologically superior option to boost herbage yield and quality of preserved fodder (hay and silage), provided that rationalization of the component crop's proportional ratio is performed. Therefore, the current study was conducted to determine the forage yield and quality of barley (Hordeum vulgare L.) and pea (Pisum sativum L.) mixtures at the ratios 100:0, 75:25, 50:50, 25:75 and 0:100. The experiment was laid out in the regular arrangement of a randomized complete block design with three replicates. The results exhibited that forage quality was significantly affected by the mixture ratio. There was a significant improvement in protein, fiber rate and digestibility from the mixture. The ratios of barley and pea with 50:50 and 25:75 produced the maximum productivity and the best quality of forage. Regarding forage preservation, silage recorded higher contents of crude protein, ash and lower fiber contents than hay. Among seed mixtures, 0:100 ratio of barley-pea yielded the highest quality of silage with the maximum crude protein, ash and digestibility with lowest fiber contents.
\end{abstract}

Keywords: forage mixture; silage quality; hay nutritive value; intercropping; nutrition qulaity; yield

\section{Introduction}

Under the changing climate, mixed cropping, which entails cereal and legume mixtures, can serve as a biologically viable approach to impart sustainability and regenerative capacity to forage production systems. Mixtures of cereals and legumes are superior to their monocultures for providing a higher yield, nutritional quality and economic turnouts to forage growers [1]. The use of annual legumes in cereal cropping systems can improve sustainability by increasing biological nitrogen $(\mathrm{N})$ fixation, reducing weed competition and escalating soil organic matter [2]. Mixed cropping of cereals with legumes has been ranked among the best agricultural practices for organic and low-input farming systems in semi-arid and arid regions of the world [3]. The uninterrupted supply of forage in sufficient quantity which has acceptable nutritional value for large and small ruminants continues to remain one of the serious challenges. The decreasing agricultural land area due to human settlements, scant irrigation supplies for crop production, farmers' interest in high-revenue generating cash crops and the persistently changing climate have all further deteriorated forage production [4]. Cereal forages, including sorghum, maize, oats, barley, millet, etc., produce a higher herbage yield but are deficient in nutritional values. On the other hand, leguminous forage crops give high nutritional values in comparatively lower quantities [5]. Therefore, it becomes pertinent to enhance forage production on a per unit area basis. Mixed cropping of cereal with legumes might serve as a pragmatic strategy to cope with the challenges of forage scarcity, inferior nutritional quality, unsustainable farming practices and deteriorating soil fertility. Additionally, legumes are rich in 
protein, and cereal has superior carbohydrate contents. At the same time, cereals, along with absorbing nutrients from soil solution, also benefit from the $\mathrm{N}$ fixed by legumes via roots intermingling and $\mathrm{N}$ contributed by legumes in the soil [6]. Moreover, other advantages offered by cereal-legume mixed cropping include better water and nutrient uptake, improved weed suppression and enhanced soil restoration and conservation [7].

Furthermore, the cultivation of mixtures contributes to the complementary use of habitat resources and compensatory growth of individual plant species, causing increased productivity and yield stability [8]. Recently, the cereal-legume mixed intercropping system has emerged as a biologically viable and economically attractive option for forage production in arid regions. The suitable species/varieties for a region get the highest yield from the cereal and legume mixtures in the mixed intercropping system [9]. However, the yield potential of mixtures and crop quality largely depends on the companion crop's selection and their relative proportion in the mixed seeded crops. The seed blending of maize and peas in 50:50 ratios recorded 50\% higher biomass than monocultures, owing to better utilization of growth resources (fertilizers and irrigation water). Similarly, sorghum-lima bean intercropping in a 80:20 ratio yielded a higher biomass by reducing the interference of weeds and preventing the leaching of nutrients. It was also inferred that mixed seeding remained more effective in $\mathrm{N}$ transfer to cereal than row or relay intercropping systems [10]. Barley-faba bean mixed seeding in a 70:30 seed-blending ratio produced $52 \%$ higher herbage yield [11]. In contrast, sorghum intercropping with cowpea using a 100:100 seed ratio yielded $18 \%$ higher biomass. When viewed alongside seed-blending ratios of 100:80, 50:50, etc., it had set a comparatively high yield [12,13]. However, Iqbal et al. [14] reported that cereal-mixed seeding with legumes (cowpea, cluster bean and soybean) in a 100:50 ratio outperformed the rest of the seed-blending ratios in terms of herbage yield and nutritional quality owing to lower inter and intraspecific competition for growth resources. Ayub et al. [15] inferred that sorghum-mixed seeding with rice bean in a 70:30 seed ratio remained effective in yielding higher biomass and nutritional quality compared to other seed-blending ratios. It was suggested that the seed-blending ratio of cereal to legume must be optimized to avoid interspecific competition for environmental (light, $\mathrm{CO}_{2}$, etc.) and farm-applied resources (moisture, fertilizers, etc.). The changing climate and conflicting findings on seed-blending ratios of cereal-legume mixed intercropping systems requires the conduction of new studies, especially for arid regions of the world, where water scarcity has worsened with the passing of time.

It was hypothesized that mixture ratios of pea and barley seeds might exhibit varying impacts on the herbage yield of component crops and on the nutritional quality of preserved fodder such as hay and silage under the arid climatic zone. Therefore, the current study was conducted to determine the impact of seed mixture ratios of pea (Pisum sativum L.) and barley (Hordeum vulgare L.) on the produced forage yield. The ultimate objective was to rationalize the most productive mixture ratio to boost herbage yield and the nutritional quality of hay and silage under arid conditions.

\section{Materials and Methods}

\subsection{Experimental Material, Treatments and Design:}

Barley (cv. Gusto.) and a local pea (var. Macrocarpon) were employed in this experiment, which was performed at the Agricultural Research and Experiment Station of College of Food and Agricultural Sciences, King Saud University (KSU), Riyadh, Saudi Arabia, during the 2014-2015 cropping season. Climatic data for the study period are shown in Table 1. Soil samples were collected at the depths ranging from 0 to $40 \mathrm{~cm}$ beneath the soil's surface before starting the experiment. After pooling all the soil samples, physical and chemical characteristics of the soil were analyzed. Analyses were performed in the laboratories of KSU and the Ministry of Environment, Water and Agriculture (MEWA) in Saudi Arabia, using an Inductively Coupled Plasma Mass Spectrometer (NexION 300D, Perkin Elmer, Waltham, MA, USA). The physical and chemical characteristics of the soil taken for this experiment are shown in Table 2. 
Table 1. Weather conditions during the study period (2014-2015).

\begin{tabular}{ccccc}
\hline & \multicolumn{2}{c}{ Average Daily Temperatures $\left({ }^{\circ} \mathbf{C}\right)$} & \multicolumn{2}{c}{ Total Rainfall $(\mathbf{m m})$} \\
\cline { 2 - 5 } & $\mathbf{2 0 1 4}$ & $\mathbf{2 0 1 5}$ & $\mathbf{2 0 1 4}$ & $\mathbf{2 0 1 5}$ \\
\hline January & 13.7 & 20.5 & 49.4 & $\mathrm{~T}^{*}$ \\
February & 15.95 & 18.5 & $\mathrm{~T}$ & 0 \\
March & 22.3 & 23.05 & 3.9 & 35 \\
April & 27.8 & 27.85 & 10.2 & $\mathrm{~T}$ \\
May & 31.95 & 32.9 & $\mathrm{~T}$ & 2 \\
June & 33.85 & 34.45 & 0 & 0 \\
July & 35.55 & 36 & 0 & 0 \\
August & 35.5 & 32.1 & 0 & 0 \\
September & 32.8 & 33.2 & 0 & 0 \\
October & 28.55 & 30.4 & 0 & 0 \\
November & 19.7 & 22.55 & 17.6 & 41 \\
December & 16.4 & 15.4 & 1.8 & 11.2 \\
\hline
\end{tabular}

Data source: Presidency of Meteorology and Environment, Saudi Arabia (2013-2015). ${ }^{*} \mathrm{~T}<1$.

Table 2. Chemical and physical properties of soils.

\begin{tabular}{cc}
\hline Parameters & Value \\
\hline $\mathrm{pH}$ & 7.14 \\
$\left.\mathrm{EC} *(\mathrm{dS} \mathrm{m})^{-1}\right)$ & 0.35 \\
Sand (\%) & 61 \\
Silt $(\%)$ & 26 \\
Clay (\%) & 13 \\
Soil texture & Sandy loam \\
$\mathrm{P}(\%)$ & 5.98 \\
$\mathrm{~K}(\%)$ & 9.78 \\
\hline
\end{tabular}

*EC: Electrical conductivity.

This experiment consisted of five seed mixing ratios of the barley and peas viz., $\mathrm{T}_{1}=100 \%$ barley, $\mathrm{T}_{2}=75 \%$ barley: $25 \%$ pea, $\mathrm{T}_{3}=50 \%$ barley: $50 \%$ pea, $\mathrm{T}_{4}=25 \%$ barley: $75 \%$ pea, and $\mathrm{T}_{5}=100 \%$ pea. The crops were sown on lines separated by $25 \mathrm{~cm}$. The sowing rates of barley and peas were 200 and $160 \mathrm{~kg} / \mathrm{ha}$, respectively. The experiment was laid out in the regular arrangement of the randomized complete block design (RCBD) with three replications. The net (excluding paths, field and plot bunds, etc.) unit plot size was $3 \mathrm{~m} \times 4 \mathrm{~m}$.

The crops were fertilized by organic fermented cow manure $\left(25 \mathrm{t}^{\text {. ha }}{ }^{-1}\right)$ and diammonium phosphate $(120 \mathrm{~kg} / \mathrm{ha})$. Urea fertilizer was added twice, at a rate of $50 \mathrm{~kg} / \mathrm{ha}$ each time. The first time was two weeks after the emergence of seedlings, and the second time was at the beginning of the spiking stage of barley. Irrigation was applied as needed according to soil moisture and rainfall. Irrigation was applied almost every week. The field capacity was reached in each irrigation. Table 3 shows the physical characteristics of the used water in the study. The experiment was kept in pest and disease-free conditions and weeds were removed manually as necessary.

Table 3. Physical properties of the used water.

\begin{tabular}{cc}
\hline Parameters & Value \\
\hline $\mathrm{pH}$ & 7.14 \\
$\mathrm{EC}^{*}\left(\mathrm{dS} \mathrm{m}^{-1}\right)$ & 0.35 \\
$\mathrm{TDS}^{* *}(\mathrm{ppm})$ & 61 \\
\hline
\end{tabular}

* EC: electrical conductivity. ${ }^{* *}$ TDS: total dissolved solids.

\subsection{Data Collection}

Growth: plant samples were taken at the beginning of the flowering stage of barley, which corresponded to the middle of the flowering stage of peas. The whole plot was 
harvested at sampling for each treatment and each replicate at a cutting height of $5 \mathrm{~cm}$. The shoot lengths of barley and pea $(\mathrm{cm})$ were measured in the randomly selected plants from the middle rows of each treatment.

Stem, leaves and spike/flower: random samples were taken for each treatment and each replicate. The leaves and the flowers/spikes were separated from the stems and branches of peas and barley tillers in order to calculate the percentages.

On hay yield and quality assessment, the fresh plant samples were taken, weighed and then dried at $65{ }^{\circ} \mathrm{C}$ for two days to estimate the dry matter percentage and dry matter yield $\left(\mathrm{t} \mathrm{ha}^{-1}\right)$. The dried samples were finely ground $(1 \mathrm{~mm})$ to evaluate all of the quality components. Similarly, for silage preparation, plant samples were taken from all treatments at the beginning of the milky phase of the barley coinciding with the formation of the pods in the peas. Plants were cut and then pressed into glass jars. The glass jars were kept in the dark under laboratory conditions. The glass jars were opened after eight months and the samples were taken out. The samples were weighed and dried at a temperature of $65^{\circ} \mathrm{C}$, and the dry matter percentage was estimated. The samples were then ground $(1 \mathrm{~mm})$, and all components of the nutritional value were assessed, using the same protocols as with hay samples.

Quality traits: The nutritive value of the forage samples from hay and silage were estimated in laboratories of Verband Deutscher Landwirtschaftlicher Untersuchungs-und Forschungsanstalten (VDLUFA) e. V., Speyer, Germany. A near-infrared spectroscopy (NIRS) instrument (Technicon 500, Technicon Industrial Systems, NY, USA) was used to determine percentages of crude ash (CA), crude protein (CP), crude fiber (CF), crude fat (CFA), water-soluble carbohydrates (WSC), neutral detergent fiber (NDF), acid detergent fiber (ADF) and digestibility (DIG) in each forage sample.

\subsection{Data Analysis}

The analyses of variance (ANOVA) were applied to determine the treatment means significance. Least significant difference (LSD) was used for the comparison of each treatment at $p \leq 0.05$. All statistical tests were performed using SPSS statistics 20.0 software (IBM, Armonk, NY, USA).

\section{Results and Discussion}

\subsection{Growth Parameters}

Growth was significantly $(p<0.01)$ affected by seed-blending ratios of barley and peas (Figure 1). The shoot length of barley was considerably decreased with an increasing ratio of pea in seed mixtures. Similarly, the increase in pea plant ratio decreased the plant height of peas. As has been stated by Ayub and Shoaib [15], the adverse effects on the plant height of legumes could be due to severe intraspecific competition for sunlight, moisture and nutrients with cereals. On the other hand, the increasing proportion of legumes in cereal-legume mixtures could result in superior performance of legumes, while cereals, such as sorghum and maize, remain dominant in mixed seeded crops, owing to superior agro-botanical traits (better plant canopy, extended roots network, etc.) [15].

The results indicate that the percentage of plant parts (stem leaves: spike/flower) of barley and pea were varied due to their mixing ratios (Figure 2). The stem ratio was significantly reduced in barley with the increased pea ratio, and this led to an increase in the level of leaves. On the other hand, the ratio for spike/flower was varied, and the best value was obtained using a 100:0 ratio $\left(\mathrm{T}_{1}\right)$. The mixture ratio significantly influenced the stem ratio, and the treatment $50 \%$ barley: $50 \%$ pea $\left(\mathrm{T}_{3}\right)$ produced the maximum value and $\mathrm{T}_{1}$ outperformed the rest of intercropping systems in terms of spike-flower ratio. The rapid growth and high yield of the cereal and of legumes ensured increased production and forage quality traits in the cereal and legume mixtures [16]. It was also reported that the production of legume-cereal mixtures could be intermediate or even lower than the productivity of monocultures because of the competition between species [17]. 


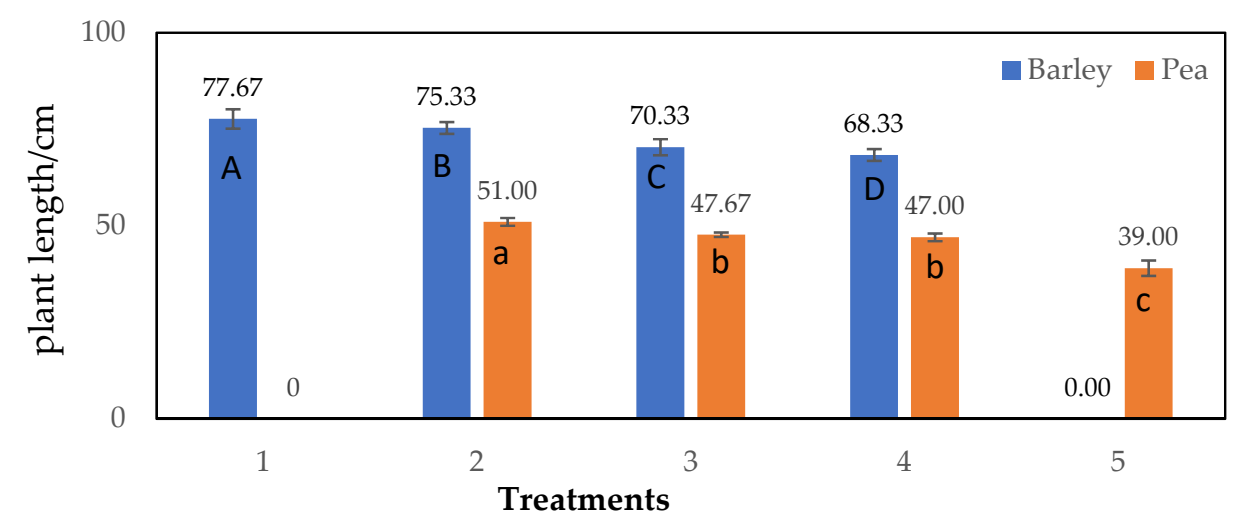

Figure 1. Effect of barley and pea seed mixing ratios on the shoot length $(\mathrm{cm})$ of grown plants. $1=100 \%$ barley, $2=75 \%$ barley: $25 \%$ pea, $3=50 \%$ barley: $50 \%$ pea, $4=25 \%$ barley: $75 \%$ pea, and $5=100 \%$ pea; Capital letters express significant differences in length between treatments in barley and small letters in pea.

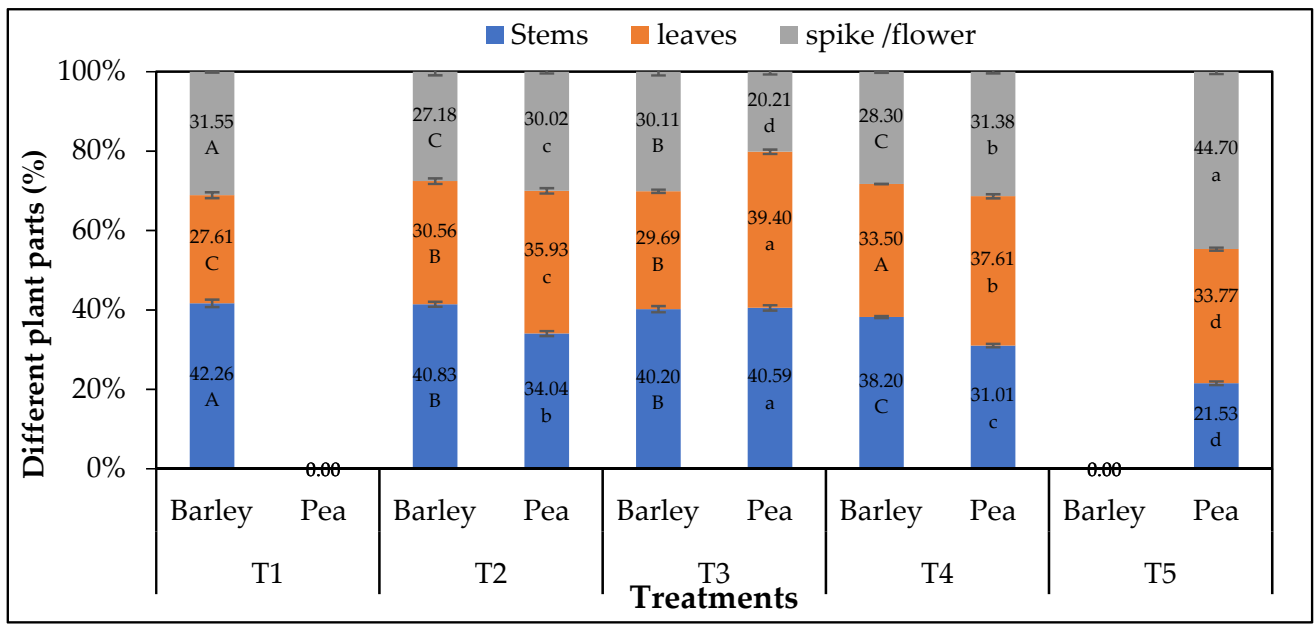

Figure 2. Effect of barley and pea mixing ratios on the different plant parts (stem:leaves:spike/flower) of barley and pea; T1 = 100\% barley, T2 = 75\% barley: $25 \%$ pea, T3 = 50\% barley: 50\% pea, T4 = 25\% barley: $75 \%$ pea, and T5 = 100\% pea. Capital letters express significant differences in plant parts between treatments in barley and small letters in pea.

\subsection{Yield and Nutritional Value of Legume-Cereal Mixturesof Hay}

In the present study, we reported that the quality of forage was significantly affected by the different mixture ratios. However, the highest values of FM $\left(\mathrm{t} \mathrm{ha}^{-1}\right), \mathrm{DM}\left(\mathrm{t} \mathrm{ha}{ }^{-1}\right)$, CA (\%), WSC (\%), NDF (\%) and ADF (\%) were recorded in the barley-pea ratio of 100:0\% $\left(\mathrm{T}_{1}\right)$, and the values decreased significantly by reducing the barley level and increasing the pea ratios. The lowest values of these nutritional traits were found in plants derived from a 0:100 barley-pea mixed intercropping system $\left(T_{5}\right)$. On the other hand, these values were increased with the decreasing density of barley. The reduction in CF (\%) and CFA $(\%)$ was prominent with the complete absence of barley in the mixture that underwent $\mathrm{T}_{5}$ treatment (Table 4). Moreover, treatment $\mathrm{T}_{5}$ showed the best results for DM (\%), CP (\%) and DIG (\%) as compared with other treatments. The increase in the proportion of cereal in mixed (legume-cereal) forages increases the yield of dry matter per unit area [6]. Annual legume-cereal mixtures usually lead to high yield and high-quality traits, compared with cereal alone [6].The most important profits of legume-cereal mixtures have been improved 
through CP yield, relative to sole cereal crops [18]. The increase in the rate of legumes in the mixtures improves the digestibility and increases the protein content; thus, the quality of forage obtained from the mixtures increases [19].

Table 4. Effect of mixture ratio (barley-pea) on the yield and nutritional value of hay forage.

\begin{tabular}{|c|c|c|c|c|c|c|c|c|c|c|c|}
\hline \multirow{2}{*}{ Treatments } & $\mathbf{F M}$ * & DM & DM & $\mathrm{CA}$ & $\mathrm{CP}$ & $\mathrm{CF}$ & CFA & WSC & NDF & ADF & DIG \\
\hline & $\left(\mathrm{t} \mathrm{ha} \mathbf{a}^{-1}\right)$ & $\%$ & (t. ha-1) & $(\%)$ & $(\%)$ & $(\%)$ & $(\%)$ & $(\%)$ & $(\%)$ & $(\%)$ & $(\%)$ \\
\hline $\mathrm{T} 1$ & $49.13 \mathrm{a}$ & $22.15 \mathrm{e}$ & $10.88 \mathrm{a}$ & $10.54 \mathrm{a}$ & $13.14 \mathrm{e}$ & $31.12 \mathrm{a}$ & $2.14 \mathrm{a}$ & $7.11 \mathrm{a}$ & $61.94 \mathrm{a}$ & $34.70 \mathrm{a}$ & $61.33 \mathrm{e}$ \\
\hline $\mathrm{T} 2$ & $45.10 \mathrm{~b}$ & $22.77 \mathrm{~d}$ & $10.27 \mathrm{ab}$ & $10.04 \mathrm{~b}$ & $13.69 \mathrm{~d}$ & $30.71 \mathrm{a}$ & $2.30 \mathrm{a}$ & $7.07 \mathrm{a}$ & $61.37 \mathrm{~b}$ & $33.86 \mathrm{~b}$ & $61.97 \mathrm{~d}$ \\
\hline T3 & $39.63 c$ & $23.61 \mathrm{c}$ & $9.36 \mathrm{bc}$ & $9.39 c$ & $14.23 \mathrm{c}$ & $31.21 \mathrm{a}$ & $2.20 \mathrm{a}$ & $6.71 \mathrm{~b}$ & $60.68 c$ & $33.15 \mathrm{c}$ & $62.93 c$ \\
\hline $\mathrm{T} 4$ & $40.57 \mathrm{c}$ & $24.10 \mathrm{~b}$ & $9.78 \mathrm{c}$ & $9.13 \mathrm{~d}$ & $14.89 \mathrm{~b}$ & $31.10 \mathrm{a}$ & $2.16 \mathrm{a}$ & $6.50 \mathrm{bc}$ & $58.90 \mathrm{~d}$ & $32.62 \mathrm{~cd}$ & $64.02 \mathrm{~b}$ \\
\hline $\mathrm{T} 5$ & $19.27 \mathrm{~d}$ & $25.05 \mathrm{a}$ & $4.83 \mathrm{~d}$ & $8.00 \mathrm{e}$ & $17.24 \mathrm{a}$ & $26.60 \mathrm{~b}$ & $1.78 \mathrm{~b}$ & $6.34 c$ & $43.42 \mathrm{e}$ & $32.29 \mathrm{~d}$ & $76.07 \mathrm{a}$ \\
\hline $\operatorname{Pr}>F$ & 0.000 & 0.000 & 0.000 & 0.000 & 0.000 & 0.000 & 0.000 & 0.000 & 0.000 & 0.000 & 0.000 \\
\hline Significant & $*$ & $*$ & * & $*$ & * & * & * & * & * & * & * \\
\hline
\end{tabular}

FM: fresh matter, DM: dry matter, CA: crude ash, CP: crude protein, CF: crude fibers, CFA: crude fat, WSC: water-soluble carbohydrates, NDF: neutral detergent fiber, ADF: acid detergent fiber, DIG: digestibility. Means followed by different letters are statistically different from each other according to Duncan's Multiple Range test at $p \leq 0.05,{ }^{*}$ : significant at $p \leq 0.05$.

\subsection{Quality Traits of Legume-Cereal Mixtures of Silage}

The silage quality traits were also significantly influenced by the barley-pea mixture ratios (Table 5). The nutritional traits of silage followed the dietary traits of hay, due to the interaction effects of barley and pea as mixture and sole. Nevertheless, the highest values of DM (\%), CP (\%) and DIG (\%) were recorded at $\mathrm{T}_{5}$ treatment (pea sole), but the values reduced with the increase in barley ratio in the mixtures. On the other hand, the CA (\%), CF (\%), CFA (\%), WSC (\%), NDF (\%) and ADF (\%) values were increased with the increase in barley ratio in the mixture. The highest values were recorded at $\mathrm{T}_{1}$ treatment $(100: 0$ of barley-pea ratio), i.e., sole barley cultivation. In contrast, the values of those traits were reduced with the increased pea ratio in the mixtures, and the lowest values were at $T_{5}$ treatment. The legumes increased the yields of $\mathrm{CP}$ of mixtures because they produced high $\mathrm{CP}$ content $[20,21]$. The increase in legume proportion caused a reduction in ADF and NDF rates for the legume-grass mixtures [22]. The quality traits of silage were improved with the increase in the ratio of barley [23]. It has been reported that ADF ratio, feed digestibility and nutrient uptake reduced with the increase in legume in the mixture [24]. The rate of NDF increased with the increase in the cereal ratio in the mixture [25]. As the ratio of the legume in the mixture increased, the protein ratio was raised [24]. The ADF and NDF ratios of mixtures were affected by the rates of legumes in mixtures due to the lower thin cell wall tissues of legume compared to the cereals [26].

Table 5. Effect of mixture ratio (barley-pea) on the quality traits of silage forage.

\begin{tabular}{cccccccccc}
\hline Treatments & $\begin{array}{c}\text { DM } \\
(\mathbf{\%})\end{array}$ & $\begin{array}{c}\text { CA } \\
\mathbf{( \% )}\end{array}$ & $\begin{array}{c}\text { CP } \\
(\%)\end{array}$ & $\begin{array}{c}\text { CF } \\
(\%)\end{array}$ & $\begin{array}{c}\text { CFA } \\
(\%)\end{array}$ & $\begin{array}{c}\text { WSC } \\
(\%)\end{array}$ & $\begin{array}{c}\text { NDF } \\
(\%)\end{array}$ & $\begin{array}{c}\text { ADF } \\
(\%)\end{array}$ & $\begin{array}{c}\text { DIG } \\
(\%)\end{array}$ \\
\hline $\mathrm{T}_{1}$ & $25.92 \mathrm{~d}$ & $12.97 \mathrm{a}$ & $14.21 \mathrm{e}$ & $29.42 \mathrm{a}$ & $3.91 \mathrm{a}$ & $6.17 \mathrm{a}$ & $57.93 \mathrm{a}$ & $32.92 \mathrm{a}$ & $63.99 \mathrm{e}$ \\
\hline $\mathrm{T}_{2}$ & $26.47 \mathrm{~d}$ & $12.44 \mathrm{~b}$ & $14.82 \mathrm{~d}$ & $28.14 \mathrm{~b}$ & $3.89 \mathrm{a}$ & $6.06 \mathrm{a}$ & $57.56 \mathrm{~b}$ & $32.39 \mathrm{~b}$ & $65.01 \mathrm{~d}$ \\
\hline $\mathrm{T}_{3}$ & $30.15 \mathrm{c}$ & $11.79 \mathrm{c}$ & $16.03 \mathrm{c}$ & $26.92 \mathrm{c}$ & $3.58 \mathrm{~b}$ & $5.76 \mathrm{~b}$ & $56.56 \mathrm{c}$ & $32.19 \mathrm{c}$ & $66.50 \mathrm{c}$ \\
\hline $\mathrm{T}_{4}$ & $33.46 \mathrm{~b}$ & $11.12 \mathrm{~d}$ & $17.26 \mathrm{~b}$ & $26.11 \mathrm{~d}$ & $3.68 \mathrm{~b}$ & $5.54 \mathrm{c}$ & $55.58 \mathrm{~d}$ & $31.19 \mathrm{~d}$ & $67.62 \mathrm{~b}$ \\
\hline $\mathrm{T}_{5}$ & $35.34 \mathrm{a}$ & $9.95 \mathrm{e}$ & $19.21 \mathrm{a}$ & $24.68 \mathrm{e}$ & $2.71 \mathrm{c}$ & $5.56 \mathrm{c}$ & $42.43 \mathrm{e}$ & $26.46 \mathrm{e}$ & $73.12 \mathrm{a}$ \\
\hline $\mathrm{Pr}>\mathrm{F}$ & 0.000 & 0.000 & 0.000 & 0.000 & 0.000 & 0.000 & 0.000 & 0.000 & 0.000 \\
\hline Significant & $*$ & $*$ & $*$ & $*$ & $*$ & $*$ & $*$ & $*$ & $*$ \\
\hline
\end{tabular}

DM: dry matter, CA: crude ash, CP: crude protein, CF: crude fibers, CFA: crude fat, WSC: water-soluble carbohydrates, NDF: neutral detergent fiber, ADF: acid detergent fiber, DIG: digestibility. Means followed by different letters are statistically different from each other according to Duncan's Multiple Range test at $p \leq 0.05$, *: significant at $p \leq 0.05$. 


\subsection{Comparative Study of Hay and Silage Quality}

It was observed that the hay contained a considerably higher amount of CF, WSC, NDF and ADF than silage. On the contrary, the silage had higher DM, CA, CP, CFA and DIG values over hay (Table 6). The yield of forage was superior in cereal monocultures compared to the pea-cereal mixtures. Pea-cereal mixtures produced superior CP content, TDN (total digestible nutrient) and RFV (relative feed value) values, compared to the monoculture of oats and barley $[6,27]$. These findings line up with $[28,29]$, in that they opined that silage prepared from cereal-legume mixtures contained higher protein content and lower fiber content, which boosted the overall nutritional values of silage for large ruminants.

Table 6. Interactive effect of hay $\times$ silage on forage qualityand yield of barley-pea mixture.

\begin{tabular}{cccccccccc}
\hline $\begin{array}{l}\text { Forage } \\
\text { Products }\end{array}$ & $\begin{array}{c}\text { DM } \\
\mathbf{( \% )}\end{array}$ & $\begin{array}{c}\text { CA } \\
\mathbf{( \% )}\end{array}$ & $\begin{array}{c}\text { CP } \\
\mathbf{( \% )}\end{array}$ & $\begin{array}{c}\text { CF } \\
(\mathbf{\%})\end{array}$ & $\begin{array}{c}\text { CFA } \\
\mathbf{( \% )}\end{array}$ & $\begin{array}{c}\text { WSC } \\
\mathbf{( \% )}\end{array}$ & $\begin{array}{c}\text { NDF } \\
(\mathbf{\%})\end{array}$ & $\begin{array}{c}\text { ADF } \\
(\mathbf{\%})\end{array}$ & $\begin{array}{c}\text { DIG } \\
(\mathbf{\%})\end{array}$ \\
\hline Hay & $23.54 \mathrm{~b}$ & $9.42 \mathrm{~b}$ & $14.64 \mathrm{~b}$ & $30.15 \mathrm{a}$ & $2.12 \mathrm{~b}$ & $6.75 \mathrm{a}$ & $57.26 \mathrm{a}$ & $33.32 \mathrm{a}$ & $65.26 \mathrm{~b}$ \\
\hline Silage & $30.27 \mathrm{a}$ & $11.65 \mathrm{a}$ & $16.31 \mathrm{a}$ & $27.06 \mathrm{~b}$ & $3.56 \mathrm{a}$ & $5.82 \mathrm{~b}$ & $54.01 \mathrm{~b}$ & $31.03 \mathrm{~b}$ & $67.25 \mathrm{a}$ \\
\hline Pr $>$ F & 0.000 & 0.000 & 0.000 & 0.000 & 0.000 & 0.000 & 0.000 & 0.000 & 0.000 \\
\hline Significant & $*$ & $*$ & $*$ & $*$ & $*$ & $*$ & $*$ & $*$ & $*$ \\
\hline
\end{tabular}

DM: dry matter, CA: crude ash, CP: crude protein, CF: crude fibers, CFA: crude fat, WSC: water-soluble carbohydrates, NDF: neutral detergent fiber, ADF: acid detergent fiber, DIG: digestibility. Means followed by different letters are statistically different from each other according to Duncan's Multiple Range test at $p \leq 0.05$, *: significant at $p \leq 0.05$.

\section{Conclusions}

The current findings aligned with the postulated research hypothesis, as varying seed-blending ratios imparted significant influence on the yield attributes, forage yield and nutritional quality of hay and silage under arid conditions. In mixtures, the peas achieved more improved protein, DIG and fiber than barley. On the other hand, barley increased the forage productions. The results showed that a mixture of pea with barley at the ratio of 50:50 $\left(\mathrm{T}_{3}\right)$ and 25:75 $\left(\mathrm{T}_{4}\right)$ was superior in yield and selected quality parameters. It can be concluded that 50:50 and 25:75 combination are the best options to grow a mixed crop of barley and peas to obtain the maximum yield and quality traits of hay and silage. The current research findings might be helpful to cover the knowledge gap of selecting the best mixture ratio of pea and barley for maximizing herbage yield, and good qualitative traits of hay and silage for ruminants in arid regions of the world. Despite the encouraging results observed during one growing season, research during multiple seasons would help strengthen the findings of the present study and possibly shed light on the long-term viability of the mixture success. In addition, the present research plan needs to be tested under different agro-climatic zones to authenticate 50:50 and 25:75 as the best combinations for maximum yield and quality of forage and silage as preserving method of feed.

Author Contributions: Conceptualization, W.S., N.A.A.-S. methodology, W.S., N.A.A.-S.; software, W.S., N.A.A.-S.; validation, W.S. and N.A.A.-S.; formal analysis, W.S., N.A.A.-S.; investigation, W.S.; resources, W.S.; data curation, N.A.A.-S.; writing-original draft preparation, W.S., N.A.A.-S.; writing-review and editing,; visualization, W.S., N.A.A.-S.; supervision, W.S.; funding acquisition, W.S., N.A.A.-S. All authors have read and agreed to the published version of the manuscript.

Funding: This research was funded by the Researchers Supporting Project number (RSP-2021/390), King Saud University, Riyadh, Saudi Arabia.

Institutional Review Board Statement: Not applicable.

Informed Consent Statement: Not applicable.

Data Availability Statement: All obtained data is enclosed with this manuscript.

Acknowledgments: Authors want to thank the Researchers Supporting Project number (RSP2021/390), King Saud University, Riyadh, Saudi Arabia. The authors thank Ayman ELSABAGH for his contributions and for the improvement of the paper. 
Conflicts of Interest: The authors declare no conflict of interest.

\section{References}

1. Yücel, C.; İnal, I.; Yucel, D.; Hatipoğlu, R. Effects of mixtureratioandcutting time on forage yield and silage quality of intercropped Berseem clover and Italian ryegrass. Legume Res. 2018, 41, 853-946.

2. Izaurralde, R.C.; Juma, N.G.; McGill, W.B.; Chanasyk, D.S.; Pawluk, S.; Dudas, M.J. Performance of conventional and alternative cropping systems in cryoborealsubhumid central Alberta. J. Agric. Sci. 1993, 120, 33-42. [CrossRef]

3. Nasar, J.; Alam, A.; Nasar, A.; Khan, M.Z. Intercropping induce changes in above and below ground plant compartments in mixed cropping system. Biomed. J. Sci. Tech. Res. 2019, 17, 13043-13050. [CrossRef]

4. Ahmad, A.H.; Ahmad, R.; Mahmood, N. Production potential and quality of mixed sorghum forage under diff erent intercropping systems and planting patt erns. Pakistan J. Agric. Sci. 2007, 44, 87-93.

5. Iqbal, M.A.; Hamid, A.; Ahmad, T.; Siddiqui, M.H.; Hussain, I.; Ali, S.; Ali, A.; Ahmad, Z. Forage sorghum-legumes intercropping: Effect on growth, yields, nutritional quality and economic returns. Bragantia 2018, 78, 82-95. [CrossRef]

6. Kocer, A.; Albayrak, S. Determination of forage yield and quality of pea (Pisum sativum L.) mixtures with oat and barley. Turkish J. Field Crops 2012, 17, 96-99.

7. Vasilakoglou, I.B.; Lithourgidis, A.S.; Dhima, K.V. Assessing common vetch:cereal intercrops for suppression of wild oat. In Proceedings of the 13th International Symposium, Session S5, European Weed Research Society, Bari, Italy, $20-23$ June 2005.

8. Klima, K.; Synowiec, A.; Puła, J.; Chowaniak, M.; Pużyńska, K.; Gala-Czekaj, D.; Kliszcz, A.; Galbas, P.; Jop, B.; Dąbkowska, T.; et al. Long-term productive, competitive, and economic aspects of spring cereal mixtures in integrated and organic crop rotations. Agriculture 2020, 10, 231. [CrossRef]

9. Lithourgidis, A.S.; Vasilakoglou, I.B.; Dhima, K.V.; Dordas, C.A.; Yiakoulaki, M.D. Forage yield and quality of common vetch mixtures with oat and triticale in two seeding ratios. Field Crops Res. 2006, 99, 106-113. [CrossRef]

10. Akdeniz, H.; Hosaflioğlu, I.; Koç, A.; Hossain, A.; Islam, M.S.; IqbaL, M.A.; Imtiaz, H.; Gharib, H.; El Sabagh, A. Evaluation of herbage yield and nutritive value of eight forage crop species. Appl. Ecol. Environ. Res. 2019, 17, 5571-5581. [CrossRef]

11. Agegnehu, G.; Ghizaw, A.; Sinebo, W. Yield performance and land-use efficiency of barley and faba bean mixed cropping in Ethiopian highlands. Eur. J.Agron. 2006, 25, 202207. [CrossRef]

12. Iqbal, M.A. Comparative performance of forage cluster bean accessions as companion crops with sorghum under varied harvesting times. Braganti 2018, 77, 476-484. [CrossRef]

13. Iqbal, M.A.; Bethune, B.J.; Asif, I.; Rana, N.A.; Zubair, A.; Haroon, Z.K.; Bilal, A. Agro-botanical response of forage sorghumsoybean intercropping systems under atypical spatio-temporal pattern. Pakistan J. Bot. 2017, 49, 987-994.

14. Iqbal, A.; Iqbal, M.A.; Hussain, I.; Siddiqui, M.H.; Nasir, M.; Ahmad, J.; Ali, Y. Seed blending of oat (Avena sativa L.) and canola (Brassica napus L.) under variable seed proportions enhanced forage productivity and nutritional quality. Pakistan J. Bot. 2018, 50, 1985-1990.

15. Ayub, M.; Shoaib, M. Studies on fodder yield and quality of sorghum grown alone and in mixture with guara under different planting techniques. Pakistan J. Agric. Sci. 2009, 46, 25-29.

16. Çınar, S. Determination of yield and quality characteristics of some cultivars and populations of tall fescue (Festuca arundinaceae Schreb.) in Çukurova Region. J. Agric. Fac. Gaziosmanpasa Univ. 2012, 2012, 29-33.

17. Carr, P.M.; Horsley, R.D.; Barley, W.W. Oat, and cereal-pea mixtures as dryland forages in the Northern Great Plains. Agron. J. 2004, 96, 677-684. [CrossRef]

18. Strydhorst, S.M.; King, J.R.; Lopetinsky, K.J.; Harker, K.N. Forage potential of intercropping barley with faba bean, lupin, or field pea. Agron. J. 2008, 100, 182-190. [CrossRef]

19. Formelová, Z.; Chrenková, M.; Mlyneková, Z.; Pozdíšek, J.; Látal, O.; Rajský, M. Protein quality of legume-cereal mixtures in ruminants'nutrition. Slovak J. Anim. Sci. 2019, 52, 171-177.

20. Kuusela, E.; Khalili, H.; Nykanen-Kurki, P. Fertilisation, seed mixtures and supplementary feeding for annual legume-grass-cereal pastures in organic milk production systems. Livest. Prod. Sci. 2004, 85, 113-127. [CrossRef]

21. Sohail, S.; Ansar, M.; Skalicky, M.; Wasaya, A.; Soufan, W.; Ahmad Yasir, T.; El-Shehawi, A.M.; Brestic, M.; Sohidul Islam, M.; Ali Raza, M.; et al. Influence of Tillage Systems and Cereals-Legume Mixture on Fodder Yield, Quality and Net Returns under Rainfed Conditions. Sustainability 2021, 13, 2172. [CrossRef]

22. Aasen, A.; Baron, V.S.; Clayton, G.W.; Dick, A.C.; McCartney, D.H. Swath grazing potential of spring cereals, field pea and mixtures with other species. Can. J. Plant Sci. 2004, 84, 1051-1058.

23. Altinok, S. A Research on determination of quality properties of barley, vetch and hairy vetch in different mixing ratios. J. Agric. Sci. 2002, 8, 232-237.

24. Seydosoglu, S. Effects of different mixture ratios of grass pea (Lathyrus sativus L.) and barley (Hordeum vulgare) on quality of silage. Legume Res. 2019, 42, 666-670. [CrossRef]

25. Ross, S.M.; King, J.R.; O'Donovan, J.T.; Spaner, D. Forage potential of intercropping berseem clover with barley, oat or triticale. Agron. J. 2004, 96, 1013-1020. [CrossRef]

26. Aşc1, Ö.Ö.; Eğritaş, Ö. Determination of forage yield, some quality properties and competition in common vetch-cereal mixtures. J. Agric. Sci. 2017, 23, 242-252. 
27. Iqbal, M.A.; Iqbal, A.; Ahmad, Z.; Raza, A.; Rahim, J.; Imran, M.; Sheikh, U.A.; Maqsood, Q.; Soufan, W.; Sahloul, N.M.; et al. Cowpea [Vigna unguiculata (L.) Walp] herbage yield and nutritional quality in cowpea-sorghum mixed strip intercropping systems. Rev. Mex. De Cienc. Pecu. 2021, 12, 402-418. [CrossRef]

28. Iqbal, M.A.; Sajid, A.; EL Sabagh, A.; Ahmad, Z.; Siddiqui, M.H. Changing climate and advances on weeds utilization as forage: Provisions, nutritional quality and implications. In Invasive Species-Introduction Pathways, Economic Impact, and Possible Management Options; Intechopen Ltd.: London, UK, 2020.

29. Iqbal, M.A.; Hussain, I.; Hamid, A.; Ahmad, B.; Ishaq, S.; EL Sabagh, A.; Barutçular, C.; Khan, R.D.; Imran, M. Soybean herbage yield, nutritional value and profitability under integrated manures management. Anais Acad. Bras. Ciências 2021, 93, e20181384. [CrossRef] [PubMed] 